\title{
Possible role of intestinal human viruses and bacteriophages following hematopoietic stem cell transplantation: a mini-review
}

\author{
Oleg V. Goloshchapov ${ }^{1}$, Alexei B. Chukhlovin ${ }^{1,2}$, Oleg S. Glotov ${ }^{2}$ \\ ${ }^{1}$ RM Gorbacheva Research Institute of Pediatric Oncology, Hematology and Transplantology, Pavlov University, St. Petersburg, \\ Russia \\ ${ }^{2}$ Children's Scientific and Clinical Center for Infectious Diseases of the Federal Medical and Biological Agency, St. Petersburg, \\ Russia
}

Dr. Alexei B. Chukhlovin, RM Gorbacheva Research Institute of Pediatric Oncology, Hematology and Transplantology, Pavlov University, 6-8 L. Tolstoy St, 197022, St. Petersburg, Russia
Phone: +7 (921) 325-00-94

E-mail: alexei.chukh@mail.ru

Citation: Goloshchapov OV, Chukhlovin AB, Glotov OS. Possible role of intestinal human viruses and bacteriophages following hematopoietic stem cell transplantation: a mini-review. Cell Ther Transplant 2021; 10(3-4): 19-25.

\section{Summary}

Gut microbiota (a complex community of bacteria, fungi and viruses) is a dynamic biological system adapted for co-existence and symbiosis with host organism. Composition and ratio of bacterial populations is severely impaired in severe colitis and graft-versus-host disease (GVHD) occurring after hematopoietic stem cell transplantation (HSCT), especially, upon development of antibiotic-resistant bacterial strains. In contrast to the well-known bacterial microbiota studied by classic bacteriology and $16 \mathrm{~S}$ rRNA gene sequencing, the viral populations of intestinal microbiota (e.g., bacteriophages) in are poorly studied in these clinical conditions, due to absence of a common viral gene suitable for comparative molecular genetic analysis. Assessing the ratios for viral and bacterial intestinal microbiota is feasible by means of metagenomic methods assaying multiple DNA species in the samples of biomaterial. As an object of clinical research, the patients with infectious complications caused by massive antibacterial and cytostatic treatment.
Special attention should be drawn to severe colitis with C.difficile infection and antibiotic-resistant K.pneumonia and other pathogens with/without fecal microbiota transplantation (FMT). Conventional assessment of intestinal microbiota will be accomplished by next-generation sequencing (NGS) based on 16S rDNA gene diversity for bacterial genes, and metagenomic NGS analysis, in order to assess the ratio of various viruses of eukaryotic cells and, in particular, bacteriophages in cases of gut dysbiosis. Typical disturbances of the gut virome should be established, as well as role of bacteriophages in emergence of antibiotic-resistant intestinal bacteria after intensive antibiotic and chemotherapy.

\section{Keywords}

Intestinal microbiota, gut microbiota, viruses, bacteriophages, transplantation, immune complications, antibiotic resistance, NGS sequencing, 16S rRNA gene, metagenomics.

\section{Introduction}

It is generally known that intestinal microbiota is a symbiotic community including many types of bacteria, fungi and viruses. It is a dynamic biological system with an average weight of $2-3 \mathrm{~kg}$, producing many metabolites (metabolic substances, vitamins, neurotransmitters, etc.) necessary for existence and growth of the host organism. The gut micro- biota interacts with intestinal epithelial cell layers which are exposed both to endogenous pathogenic (e.g., blood-borne) viruses, and to intestinal bacterial populations. In turn, the gut microbed strains are affected by various bacteriophage populations causing their lysis. The surviving bacteria may acquire mobile gene elements, including those providing resistance to antibiotics (Fig. 1). These polyresistant bacteria are an important cause of life-threatening infections in 
immunocompromised patients, e.g., after intensive cytostatic therapy and hematopoietic stem cell transplantation (HSCT).

Moreover, the host immune system develops in permanent contact with the surrounding microbial and viral antigens, especially with the endogenous intestinal microbiota, which includes all these components [1]. Microbial and viral antigens of the intestinal microbiota, passing through the epithelial barriers of the mucous membranes, penetrate into the regional blood vessels and lymph nodes, form an adaptive $\mathrm{B}$ - and T-cell immune response, being a key factor in the normal maturation and functioning of the immune system.

For decades, the main attention of bacteriologists was paid to cultivated, mainly aerobic microorganisms - Escherichia, Klebsiella, Enterococci that were studied in details for decades. Cultivable anaerobic gut bacteria were also exhaustively studied over last decades. However, with development of high-throughput DNA diagnostics, the spectrum of known microbial bacteria extended to sufficient degree. Currently, $>1000$ bacterial species are detectable in normal gut microbiota. Hence, over the past 10-20 years, the novel molecular biology approaches (multiple PCR, high-throughput DNA sequencing) enabled detailed classifying hundreds of species of anaerobic intestinal bacteria, which dominate the intestinal microbiota.
Human viral community (virome) is exhibiting even higher taxonomic and genetic complexity. Formerly, the main interest was drawn to the viruses of eukaryotic cells which could be pathogenic to humans. The modern NGS approach allows to detect both known viruses (herpes, anelloviruses, picobirnaviruses) and a number of previously unknown viral DNA sequences [2].

However, intestinal human virome is dominated by bacteriophages. These are largely represented by Caudiovirales. [3]. This order of phages includes 3 families (Myoviridae; Siphoviridae, and Podoviridae).

Along with double-stranded DNA phages, minor populations of single-stranded DNA and RNA phages are detectable in human gut virome which are also specific for distinct bacterial species as reviewed by Carding et al. [3].

The issues of viral sequences in bacterial and human cells (e.g., prophages, retroviral elements etc.) are also detectable by metagenomics but will not be covered here, because of undefined clinical significance and still undefined systemic approach. Hence, the question about functions and significance of virome abundance and diversity in healthy subjects and GIT disorders is still open.

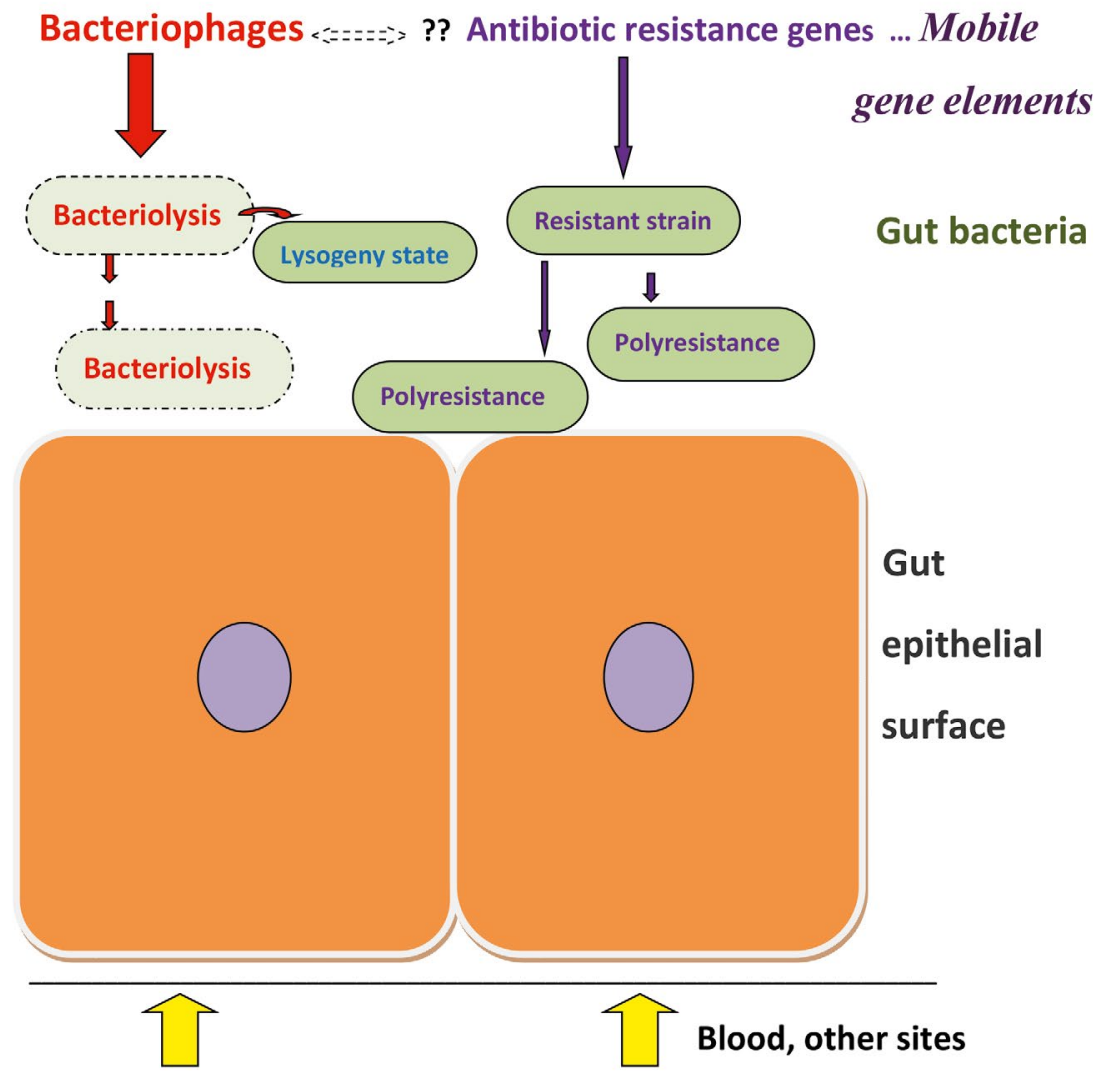

Human cell viruses (e.g., herpes group)

Figure 1. Intestinal epithelium is exposed to endogenous host viruses (bottom), and interacts with gut bacteria (light green) which could be lysed by bacteriophages (top left). Some of them may harbor and transfer antibiotic resistance genes to the bacteria (top right) 


\section{Current methodology}

Unlike the bacterial microbiota, viral intestinal population (gut virome) has been studied to a much lesser extent. Whereas bacterial species have the common target gene for sequencing, i.e., 16SrRNA (the main object for NGS analysis), the viruses lack such a common marker gene, thus hampering easy assessment of their diversity in biological samples.

Currently, there is a broad diagnostic choice in clinical virology, starting with cytopathogenic tests, large arrays of immune diagnostic sets, and modern whole-scale panels of PCR assays. To diagnose some pathogenic viruses (up to 10-15 species), multiplex PCR was developed, and it is commonly used in clinical laboratories. However, these commercial PCR panels cannot cover the entire spectrum of potential viral agents, usually targeting up to 10-12 pathogens.

Therefore, the most comprehensive approach to studying the entire viral community is whole-genome screening of viral sequences by means of NGS followed by extensive bioinformatics. E.g., a random metagenomic analysis may also allow detection of human pathogenic viruses. Methodology of metagenomic studies are well reviewed in [4].

\section{Diversity of human viruses and bacteriophages}

A number of endogenous viruses persisting lifelong may be found in stools under certain conditions, e.g., in immunocompromised patients or during immunosuppressive therapy.

Herperviruses in gut are often activated in the patients with inflammatory bowel diseases. E.g., the Japanese group, using high-capacity multiplex PCR with microchip electrophoresis, has detected as much as 191 different bacterial species and 206 viruses in 215 stool samples ( $71.7 \%$ positivity) from immunocompromised patients and subjects with ulcerative colitis [5]. Among viral pathogens, Epstein-Barr virus (EBV) was revealed in 90 samples (30.0\%); HHV-6, in 53 cases $(17.7 \%)$, and cytomegalovirus (CMV) in 37 specimens $(12.3 \%)$.

Most often, however, human intestinal microbiome is extensively studied in search of the viruses known to be pathogenic (i.e., noroviruses, rotaviruses, astroviruses, adenoviruses etc.). Biological diversity of human pathogenic viruses was first studied in Asian countries, with high incidence of gastroenteritis in pediatric setting [6]. The authors examined stool samples from 7 children positive for picobirnavirus and identified, by means of metagenomics, enterovirus, gyrovirus, parechovirus in these samples, which are potentially pathogenic in gastroenteritis. In addition, a metagenomic study of stool microbiota allows detecting bacterial-viral associations (for example, C.difficile associated with a number of viruses) in intestinal syndromes as shown by a group from the USA [7]. Metagenomic analysis was also used for NGS analysis of stool samples in gastroenteritis, and, except of common noroviruses, additional pathogens were found from the genus Astroviridae and Caliciviridae [8].

\section{Gut human virome after HSCT}

A limited number of works concerned presence of intestinal viruses posttransplant. E.g., Legoff et al. have detected different viruses in stool and plasma following HSCT using electrospray ionization with mass-spectrometric [9]. The workers have revealed high adenovirus (AdV) viral load in stool samples. In an earlier study, AdV DNA was found in stools of 21 HSCT patients with AdV infection, from a total group of 182 patients. Of note, time dynamics of AdV viral loads in stool specimens was predictive for AdV viraemia, thus suggesting intestinal source to be the primary site of the viral infection [10].

Cytomegalovirus (CMV) viral load was assessed in stool of HSCT as possible marker of acute intestinal graft-versushost disease posttransplant [11]. CMV DNA was found in 20 of 121 HSCT recipients. However, the authors did not find any correlation between CMV DNA loads and intestinal graft-versus-host disease (aGVHD), as well between viral contents in plasma and stools.

In view of scarce NGS-based virome studies in HSCT, it is very important to detect and realize significance of multiple viral species in progression of intestinal syndrome. Over the past 5 years, several papers have been published on the metagenomics of viruses after HSCT [12]. The authors traced the virome dynamics in 44 HSCT recipients using metagenomics techniques (NexTera, HiSeq platforms). Following transplantation (i.e., during transient immune deficiency), Anelloviridae, herpes viruses, papilloma and polyoma viruses, especially picobirnavirus were "flourishing" in intestinal GVHD. Moreover, decreased detection rates were noted for bacteriophages, except for Siphoviridae. A similar work was carried out by a Dutch group [13]. The authors used the original ViroCap system to study fecal samples, with a large panel of probes for 34 families of DNA and RNA viruses (a total of 337 species). After enrichment of viral DNA in the samples, the NGS procedures were performed. At the same time, it was possible to identify, along with known noro- and adenoviruses, also rhinovirus, herpesvirus-7, VK virus, astrovirus at higher sensitivity, than with conventional PCR tests. This approach revealed new associations between the findings of viral sequences and intestinal GVHD. Temporal changes of the patient's microbiota after GVHD and weekly fecal microbiota transplantation in a single patient was studied by Chinese workers [14]. Biodiversity of bacterial species gradually increased after successful TFM, whereas the spectrum of viruses, in general, expanded with time after FMT, e.g., Caudivirales content was increased.

\section{Intestinal phageome}

Current metagenomic approaches allowed to look for the whole spectrum of virome, including human viruses and bacteriophages in human microbiota which seems to become a feasible task of clinical significance [15].

For more than 100 years, the bacteriophages were extensively studied using bacteriolysis in classical cultures, morphological and, later molecular PCR methods. Therefore, current criteria for bacteriophage classification are based on their 
biological properties (lytic or temperate forms; bacterial targets), morphology, main location site etc. [16].

Some of the bacteriophages are widely used in clinical practice to combat antibiotic-resistant bacteria [17].

However, the full-scale analysis of multiple phage populations became available only few years ago, with an advent of high-throughput metagenomic sequencing performed at various NGS platforms [18].

This approach makes it possible to assess the entire community of pathogenic viruses, especially, different bacteriophage species in fecal samples. Different bacteriophages are, generally, specific for distinct bacterial species [19]. Therefore, spectrum and content of intestinal bacteriophages, by definition, depends on the dynamics of the bacterial hosts in the microbiota, and vice versa. Dietary habits, age and antibiotic therapy may influence composition and dynamics of both bacteria and their phages. E.g., starting from birth, the Caudovirales content and phage biodiversity change significantly with age [18].

Shotgun metagenomic methods allow evaluating the entire population of genes in a sample (though at different detection efficiencies). E.c., French authors have applied this technique to study the intestinal bacterial microbiota upon exposure to antimicrobial drug (cefprozil) Immediately after therapy, the total content of metagenomic sequences was expected to decrease. However, 3 months after the therapy, new previously absent gene sequences appeared in the intestinal microbiota and, what is important, the content of antibiotic resistance signatures increased, especially in individuals with initially low biodiversity of the intestinal microbiota. [20]. Different mechanisms of horizontal gene transfer via bacteriophages are shown in Fig. 2.

\section{Metagenomic studies of intestinal phageome and resistance genes}

Previous knowledge of intestinal virome was, mostly, based on classical studies of bacteriophages detectable by their bacteriolytic effects. Tremendous information on intestinal phages accumulated over XX century. The data on eukaryotic cell viruses are also quite extensive, mostly concerning distinct pathogenic viral species.

Current technical advances, i.e., next-generation sequencing (NGS) enabled coverage of the whole intestinal virome. Metagenomics makes it possible to identify and evaluate both temporal dynamics of phage populations, and their relationship with antibiotic resistance genes that promoting colonization of intestines by pathogenic bacterial strains.

Over the past 3-5 years, the work was started with searching phage sequences and antibiotic resistance genes using new generation sequencing (NGS) methods. Thus, Fernández-Orth et al. investigated DNA from samples of intestinal microbiota in healthy individuals and after treatment with ciprofloxacin, using deep sequencing methods (MySec, Illumina). Assembly of the sequences obtained was evaluated using Kraken software. The samples were found to contain from 4 to 266 viruses. Caudovirales predominated among bacteriophages, and the phages of Siphoviridae and Myoviridae families were also identified. Antibiotic resistance genes were also found in bacterial DNA, and their content was significantly increased after treatment with ciprofloxacin [22].

In other study, bioinformatic analysis of multiple viral sequences from human intestinal microbiome was carried out 4 weeks after a course of antibiotics. The authors found

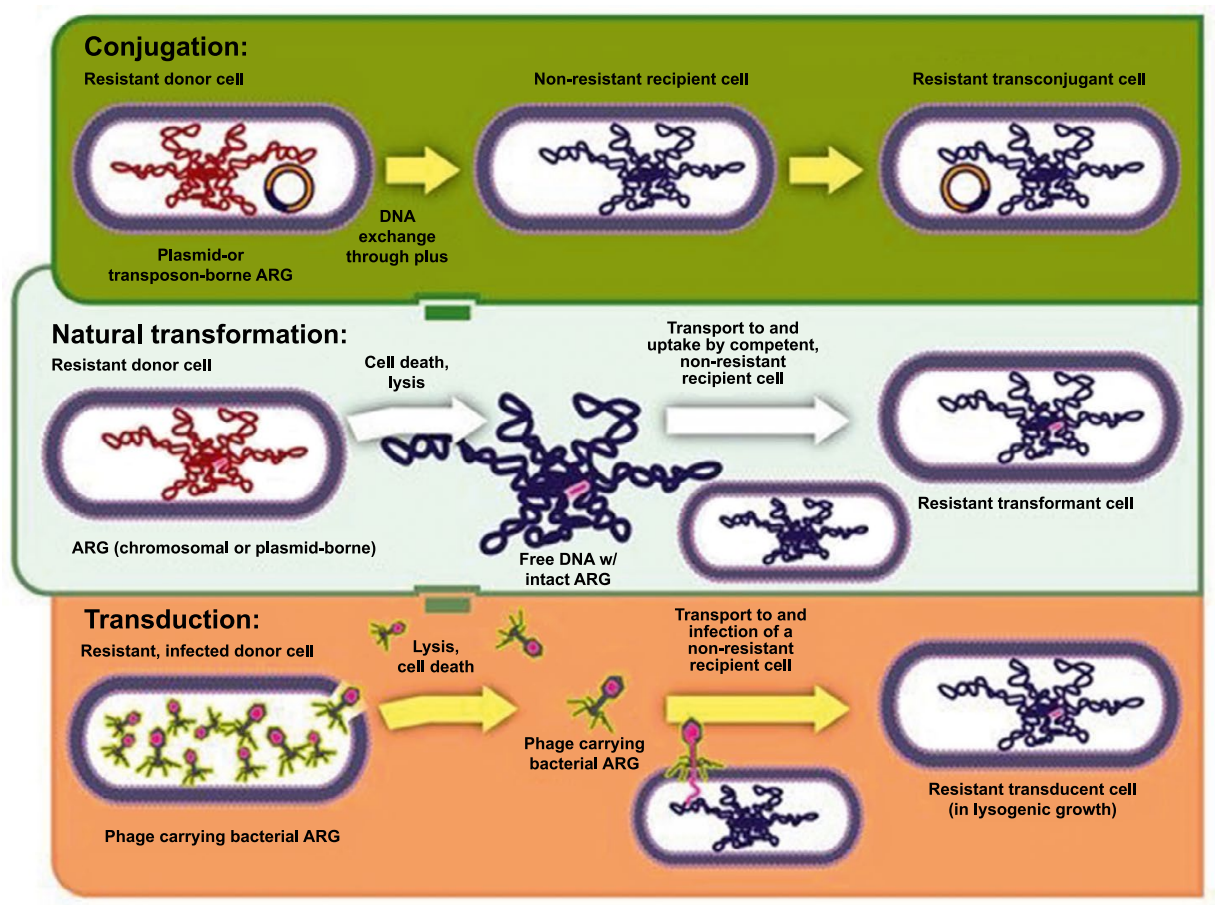

Figure 2. Horizontal gene transfer can commonly occur through conjugation and natural transformation. Additionally, it may occur through transduction, where resistance is transmitted via bacteriophage. (From [21]) 
a significant increase in the number of gene signatures (scaffolds) of antibiotic-resistant genes after antibiotic therapy [23].

However, current evidence show that the antibiotic resistance genes can be inserted into plasmids and other mobile genetic elements, which can be transmitted both vertically and by horizontal transfer within the bacterial population, which is essential for accumulation of resistant strains within the intestinal microbiota. Such evidence has been obtained recently. For example, gene sequences were screened for 254 strains of Klebsiella pneumoniae, which most often acquires the drug resistance genes [24]. They showed that most of the studied strains contained intact prophage sequences. An additional analysis of 42 K.pneumoniae strains showed that these phages belong to the families Myoviridae, Siphoviridae, and Podoviridae. Interestingly, no virulence genes were detected in these prophages; however, in $2 \%$ of cases, these prophages also encoded genes related to antibiotic resistance factors.

\section{Probable bacteria-phage interactions in HSCT patients}

However, most of these clinical studies dealt with the state and ways of restoring the bacterial component of the microbiota, while missing possible role of bacteriophages in severe intestinal dysbiosis. The latter direction can also be promising, as shown by the data of NGS studies on the stability of intestinal bacteriophage populations during fecal transplantation [25]. Meanwhile, there are still no proven positive results from phage therapy in severe intestinal dysbiosis. It is believed that in the future it will be possible to develop modified bacteriophages adapted to specific resistant bacteria [26]. So far, however, there is a process of accumulating information about the bacterial-viral complex of the intestinal microbiota in severe intestinal syndromes of infectious origin.

Posttransplant period is often associated with severe colitis often associated to persistent infection with K.pneumoniae, pathogenic E.coli, C.difficile as reviewed in [27]. Meanwhile, treatment of bacterial infections using species-specific bacteriophages, in particular - those against Staphylococci, E. coli, etc. has been successfully used for decades. The history of these developments is well described [17]. However, the desirable clinical effects were temporary, often due to the development of resistance to phage therapy [19]. British scientists have discovered that optimal combinations of several bacteriophages are most effective in suppressing and preventing phage resistance of C.difficile, as was previously shown experimentally [28]. In hamster experiments, treatment with optimized phage mixtures led to rapid decrease in the C.difficile colonization. Clinical transplantation of intestinal microbiota also suggests possible clinical effects of non-bacterial pathogens. E.g., Ott et al. [29] administered sterile filtrates of donor stool through a nasal cannule to the patients with Clostridium difficile infection. Usage of this bacteria-free drug in 5 patients led to long-term normalization of intestinal disorder, as well as appropriate changes in bacterial and intestinal microbiota. The authors suggest that bacteriophages from the stool filtrate may cause similar positive effects. Hence, these findings enable search and identification of intestinal bacteriophages associated with positive and persistent effects of colitis therapy, especially at the present time, when effective methods of metagenomic DNA sequencing are developed for such studies.

\section{Conclusion}

Gut microbiota is a complex symbiosis of bacteria, viruses and fungi. However, unlike the bacterial microbiota (bacteriome), the viral gut community (gut virome) is studied to much lesser degree, due to absence of common target gene for nucleic acid sequencing in viruses. Over last years, the whole-genome screening techniques using next-generation sequencing (NGS) promoted our knowledge in the field. This approach allowed to estimate the biodiversity of human viruses and bacteriophages in the individual samples of intestinal microbiota in health and disease.

Studies of the virome changes after HSCT are now launched, however, being at initial stage. Meanwhile, the changes in bacteriophage community (phageome) and its diversity post-transplant may explain both therapy-associated changes of bacteriome, and development of bacterial antibiotic resistance, due to phage-mediated transfer of antibiotic resistance genes.

\section{Conflicts of interest}

None conflicts of interest are declared.

\section{Acknowledgements}

The authors are much appreciated to the Pediatric Research and Clinical Center for Infectious Diseases, and dedicate the present article to the $95^{\text {th }}$ anniversary of this institution.

\section{References}

1. Shi N, Li N, Duan X, Niu H. Interaction between the gut microbiome and mucosal immune system Mil Med Res 2017; 4:14. doi: 10.1186/s40779-017-0122-9

2. Smits SL, Schapendonk CM, van Beek J, Vennema H, Schürch AC, Schipper D, et al. New viruses in idiopathic human diarrhea cases, the Netherlands. Emerg Infect Dis. 2014; 20(7):1218-22. doi: 10.3201/eid2007.140190

3. Carding SR, Davis N, Hoyles L. Review article: the human intestinal virome in health and disease. Aliment Pharmacol Ther. 2017; 46(9):800-815. doi: 10.1111/apt.14280

4. Gu W, Miller S, Chiu CY. Clinical Metagenomic Next-Generation Sequencing for Pathogen Detection. Annu Rev Pathol. 2019; 14:319-338. doi: 10.1146/annurev-pathmechdis-012418-012751

5. Nahar S, Iraha A, Hokama A, Uehara A, Parrott G, Ohira T, et al. Evaluation of a multiplex PCR assay for detection of cytomegalovirus in stool samples from patients with ulcerative colitis. World J Gastroenterol. 2015; 21(44):12667-75. doi: $10.3748 /$ wjg.v21.i44.12667 
6. Sun G, Zang Q, Gu Y, Niu G, Ding C, Zhang P. Viral metagenomics analysis of picobirnavirus-positive feces from children with sporadic diarrhea in China. Arch Virol. 2016; 161 (4): 971-5. doi: 10.1007/s00705-015-2726-2

7. Zhou Y, Wylie KM, El Feghaly RE, Mihindukulasuriya KA, Elward A, Haslam DB, Storch GA, Weinstock GM. Metagenomic Approach for Identification of the Pathogens Associated with Diarrhea in Stool Specimens. J Clin Microbiol. 2016; 54 (2): 368-75. doi: 10.1128/JCM.01965-15

8. Fernandez-Cassi X, Martínez-Puchol S, Silva-Sales M, Cornejo T, Bartolome R, Bofill-Mas S, Girones R. Unveiling Viruses Associated with Gastroenteritis Using a Metagenomics Approach. Viruses. 2020; 12 (12): 1432. doi: 10.3390/ $\underline{\text { v12121432 }}$

9. Legoff J, Feghoul L, Mercier-Delarue S, Dalle JH, Scieux C, Chérot J, et al. Broad-range PCR-electrospray ionization mass spectrometry for detection and typing of adenovirus and other opportunistic viruses in stem cell transplant patients. J Clin Microbiol. 2013; 51(12):4186-92. doi: 10.1128/ JCM.01978-13

10. Jeulin H, Salmon A, Bordigoni P, Venard V. Diagnostic value of quantitative PCR for adenovirus detection in stool samples as compared with antigen detection and cell culture in haematopoietic stem cell transplant recipients. Clin Microbiol Infect. 2011;17(11):1674-80. doi: 10.1111/j.14690691.2011.03488.x

11. Bueno F, Albert E, Giménez E, Piñana JL, Pérez A, Gómez $\mathrm{MD}$, et al., 2020. Cytomegalovirus DNA load monitoring in stool specimens for anticipating the occurrence of intestinal acute graft-versus-host disease following allogeneic hematopoietic stem cell transplantation: Is it of any value? Transpl Infect Dis. 2020; 22(6):e13440. doi: 10.1111/tid.13440

12. Legoff J, Resche-Rigon M, Bouquet J, Robin M, Naccache $\mathrm{SN}$, Mercier-Delarue S, et al. The eukaryotic gut virome in hematopoietic stem cell transplantation: new clues in enteric graft-versus-host disease. Nat Med. 2017; 23 (9): 1080-1085. doi: $10.1038 / \mathrm{nm} .4380$

13. Jansen SA, Nijhuis W, Leavis HL, Riezebos-Brilman A, Lindemans CA, Schuurman R. Broad virus detection and variant discovery in fecal samples of hematopoietic transplant recipients using targeted sequence capture metagenomics. Front Microbiol. 2020; 11: 560179. doi: 10.3389/ fmicb.2020.560179

14. Zhang F, Zuo T, Yeoh YK, Cheng FWT, Liu Q, Tang W, et al. Longitudinal dynamics of gut bacteriome, mycobiome and virome after fecal microbiota transplantation in graft-versus-host disease. Nat Commun. 2021; 12 (1): 65. doi: 10.1038/s41467-020-20240-X

15. Wang W, Jovel J, Halloran B, Wine E, Patterson J, Ford G, et al. Metagenomic analysis of microbiome in colon tissue from subjects with inflammatory bowel diseases reveals interplay of viruses and bacteria. Inflamm Bowel Dis. 2015; 21 (6): 1419-27. doi: 10.1097/MIB.0000000000000344

16. Principi N, Silvestri E, Esposito S Advantages and Limitations of Bacteriophages for the Treatment of Bacterial Infections. Front. Pharmacol. 2019;10:513. doi: 10.3389/ fphar.2019.00513
17. Brüssow H. Phage therapy for the treatment of human intestinal bacterial infections: soon to be a reality? Exp Rev Gastroenterol Hepatol. 2017. doi: 10.1080/17474124.2017.1342534

18. Townsend EM, Kelly L, Muscatt G, Box JD, Hargraves N, Lilley D, Jameson E. The human gut phageome: Origins and roles in the human gut microbiome. Front Cell Infect Microbiol. 2021; 11: 643214. doi: 10.3389/fcimb.2021.643214

19. Oechslin F. Resistance development to bacteriophages occurring during bacteriophage therapy. Viruses 2018, 10, 351. doi: $10.3390 / \mathrm{v} 10070351$

20. Raymond F, Déraspe M, Boissinot M, Bergeron MG, Corbeil J. Partial recovery of microbiomes after antibiotic treatment. Gut Microbes. 2016; 7 (5): 428-34. doi: 10.1080/ $\underline{19490976.2016 .1216747}$

21. Schroeder M, Brooks BD, Brooks AE. The Complex Relationship between Virulence and Antibiotic Resistance. Genes. 2017; 8(1):39. https://doi.org/10.3390/genes8010039

22. Fernández-Orth $\mathrm{D}$, Miró E, Brown-Jaque $\mathrm{M}$, Rodríguez-Rubio L, Espinal P, Rodriguez-Navarro J, et al. Faecal phageome of healthy individuals: presence of antibiotic resistance genes and variations caused by ciprofloxacin treatment. J Antimicrob Chemother. 2019; 74 (4): 854-864. doi: $10.1093 / \mathrm{jac} / \mathrm{dky} 540$

23. Górska A, Peter S, Willmann M, Autenrieth I, Schlaberg $\mathrm{R}$, Huson DH. Dynamics of the human gut phageome during antibiotic treatment Comput Biol Chem. 2018; 74: 420427. doi: 10.1016/j.compbiolchem.2018.03.011

24. Baliga P, Shekar M, Kallappa GS. Genome-wide identification and analysis of chromosomally integrated putative prophages associated with clinical Klebsiella pneumoniae strains. Curr Microbiol 2021; 78 (5): 2015-2024. doi: $10.1007 / \mathrm{s} 00284-021-02472-2$

25. Broecker F, Russo G, Klumpp J, Moelling K. Stable core virome despite variable microbiome after fecal transfer. Gut Microbes. 2017; 8 (3): 214-220. doi: 10.1080/ $\underline{19490976.2016 .1265196}$

26. Paule A, Frezza D, Edeas M. Microbiota and phage therapy: Future challenges in medicine. Med Sci (Basel). 2018; 6 (4): 86 . doi: $10.3390 /$ medsci6040086

27. Goloshchapov OV, Kucher MA, Chukhlovin AB. Gut microbiome in hematopoietic stem cell transplantation: patient-and treatment-related factors. Cell Ther Transpant. 2018; 7(4): 16-28. doi: 10.18620/ctt-1866-8836-2018-7-4-16$\underline{28}$

28. Nale JY, Spencer J, Hargreaves KR, Buckley AM, Trzepiński P, Douce GR, Clokie MR. Bacteriophage combinations significantly reduce Clostridium difficile growth in vitro and proliferation in vivo. Antimicrob Agents Chemother. 2015; 60 (2): 968-981. doi: 10.1128/AAC.01774-15

29. Ott SJ, Waetzig GH, Rehman A, Moltzau-Anderson J, Bharti R, Grasis JA, et al. Efficacy of sterile fecal filtrate transfer for treating patients with Clostridium difficile infection. Gastroenterology. 2017; 152 (4): 799-811.e7. doi: 10.1053/ j.gastro.2016.11.010 


\title{
Потенциальная роль вирусов человека и бактериофагов после трансплантации гемопоэтических стволовых клеток: мини-обзор
}

\author{
Олег В. Голощапов ${ }^{1}$, Алексей Б. Чухловин ${ }^{1,2}$, Олег С. Глотов ${ }^{2}$ \\ ${ }^{1}$ НИИ детской онкологии, гематологии и трансплантологии им. Р. М. Горбачевой, Первый Санкт-Петербургский \\ государственный медицинский университет им. акад. И. П. Павлова, Санкт-Петербург, Россия \\ 2 Детский научно-практический центр инфекционных болезней ФМБА, Санкт-Петербург, Россия
}

\section{Резюме}

Микробиота кишечника (сложный симбиоз бактерий, грибов и вирусов) - это динамическая биологическая система, необходимая для существования и роста человеческого организма. Состав и соотношение бактериальных популяций серьезно нарушаются при тяжелых колитах и болезни «трансплантат против хозяина» (GVHD), возникающих после трансплантации гемопоэтических стволовых клеток (HSCT), особенно при развитии устойчивых к антибиотикам бактериальных штаммов. В отличие от хорошо известной бактериальной микробиоты, изученной с помощью классической бактериологии и секвенирования гена $16 \mathrm{~S}$ pРНК, вирусные популяции кишечной микробиоты (например, бактериофагов) в этих клинических условиях изучены недостаточно из-за отсутствия общего вирусного гена, пригодного для сравнительного молекулярно-генетического анализа. Оценка соотношений вирусной и бактериальной кишечной микробиоты возможна с помощью метагеномных методов анализа множества видов ДНК в образцах биоматериала. Объектом клинического исследования являются пациенты с инфекционными осложнениями, вызванными массивным антибактериальным и цитостатическим лечением.
Особое внимание следует обратить на тяжелый колит с инфекцией C.difficile и устойчивой к антибиотикам K. pneumoniae, а также другими патогенами, как при трансплантации фекальной микробиоты (FMT), так и без нее. Обычная оценка кишечной микробиоты будет осуществляться путем секвенирования следующего поколения (NGS) на основе генного разнообразия $16 \mathrm{~S}$ рДНК для бактериальных генов и метагеномного анализа NGS, чтобы оценить соотношение различных вирусов эукариотических клеток и, в частности, бактериофагов в случае дисбактериоза кишечника. Следует установить типичные нарушения кишечного вирома, а также их роль в колонизации кишечными бактериями, устойчивыми к антибиотикам, после интенсивной антибиотикотерапии и химиотерапии.

\section{Ключевые слова}

Кишечные инфекции, трансплантация, иммунологические осложнения, кишечная микробиота, вирусы, бактериофаги, антибиотикорезистентность, секвенирование нового поколения (NGS), ген $16 \mathrm{~S}$ rRNA, метагеномика. 